\title{
MÓNIKA PAPP* \\ Application of EU competition law by the Hungarian judiciary \\ Cooperation with the ECJ and relying on the case-law of the ECtHR
}

\section{INTRODUCTION}

This paper will address some aspects of the application of EU antitrust rules by the Hungarian judiciary. The main focus of the first part of the paper will be on the procedural framework these rules are applied within and the cooperation with the European Court of Justice (ECJ) via preliminary rulings. In this first part I will first sketch the contours of requesting a preliminary ruling from the ECJ as an ordinary practice of Hungarian courts. Hungarian courts are quite active in applying EU law and posing preliminary rulings to the ECJ. If we have a quick look on the statistics, we can detect different areas of EU law where this phenomenon is visible. The most numerous group of cases deals with tax law generally and VAT tax law specifically. The second biggest area with significant number of requests for a preliminary ruling is the EU consumer law acquis, where the unfair contract terms directive is applied in most of the cases. ${ }^{1}$ Antitrust rules were referred to the ECJ in two cases, in Allianz and Generali.

As Hungarian courts are very active in posing preliminary questions, it comes as a surprise that in competition law matters the judiciary seems to be more inclined to autonomously interprer EU competition law without the help of the ECJ. From accession until 2015 only two ECJ judgements were adopted under the request of Hungarian courts on antitrust matters, in cases Allianz ${ }^{2}$ and Generali ${ }^{3}$.

In the second part of the paper, the context is changed and I will turn the attention of the reader to another challenge posed by the European Convention on Human Rights ${ }^{4}$. Being a signatory to the Convention not only Union law, but also the law of the Convention os binding on Hungarian courts. The standard of judicial review in competition cases is put to a test by the European Court of Human Rights (EctHR) under the right to a fair trial. The penal nature of antitrust procedures and its implication on the standard of proof was in the center of discussion at the highest courts level in Hungary. Before I provide a deeper examination of a recent Supreme Court judgement and a

\footnotetext{
${ }^{1}$ Somssich Réka: Előzetes döntéshozatali eljárások a számok tükrében- a 2004-ben csatlakozott országok bíróságai által kezdeményezett eljárások 10 évvel a csatlakozás után. Európai Jog, 2015/2. pp. 1-13.

*Associate Professor, University of Eötvös Loránd, Law School, Budapest. Research Fellow at the Hungarian Academy of Sciences, Center for Social Sciences, HPOPs- Lendület Research Group. Research was also financed by OTKA (No K-109414 project)

The author would like to thank Márton Varju, Zoltán Marosi and András Kovács for their helpful comments on this topic. Any error or omission is mine.

${ }^{2}$ C- 32/11. Hungária Biztosító Zrt v Gazdasági Versenyhivatal, ECLI:EU:C:2013:160

3 C-470/13. Generali-Providencia Biztosító Zrt v Közbeszerzési Hatóság Közbeszerzési Döntőbizottság, ECLI:EU:C:2014:2469

${ }^{4}$ Convention for the Protection of Human Rights and Fundamental Freedoms, Act XXXI of 1993
} 
Constitutional Court judgement, I briefly explain the position of the European Court of Justice on the standard of judicial review and the right to a fair trial.

\section{CHAPTER 1.}

\section{THE NATIONAL CONTEXT}

The pre-accession period goes back to 1991 when the Europe Agreement was signed, by which Hungary was obliged to approximate its national law, particularly among other areas, competition law with European Community law as far as possible ${ }^{5}$. A year before, in 1990 the first Competition Act was adopted by the Parliament after the transformation to market economy and an independent agency, the Hungarian Competition Office (Gazdasági Versenyhivatal or GVH) was established to enforce competition law. Later, Act LVII of 1996 on the prohibition of unfair and restrictive market practices (hereinafter: Hungarian Competition Act or HCA) came into force and regulates competition law in Hungary after several amendments. Article 11 of the Act contains a prohibition modelled on the text of Article 101 TFEU. ${ }^{6}$ Article 21 of the HCA entails a prohibition on abuse of a dominant position. ${ }^{7}$ The Preamble of the HCA refers to EU competition law as a model for formulating domestic legislation. ${ }^{8}$ Voluntary law approximation has taken place after Hungary's accession to the EU, the most important modifications were introduced in procedural law under Council Regulation $1 / 2003 / E^{9}$. The former notification system was abolished and the GVH received powers similar to the European Commission's ${ }^{10}$.

Administrative decisions of the GVH are frequently based on Article 101-102, alongside national competition law. According to the practice, the reasoning of a GVH decision follows a compound pattern, meaning that the reasoning based on EU law and Hungarian law is not divided in separate sections. The HCA relied on the similar wording of the two legal basis to justify its position that there is no need to apply these provisions separately. The HCA consistently uses EU hard and soft law to substantiate its decisions, even in cases decided exclusively upon Hungarian competition law. National courts reviewing GVH decisions agreed with this approach. In 2010 in the Allianz case ${ }^{11}$ the Supreme Court argued that in decisions based solely on Article 11 of the HCA, the GVH can base its

\footnotetext{
${ }^{5}$ Europe Agreement establishing an association between the European Communities and their Member States, of the one part, and the Republic of Hungary, of the other part, OJ L 347, 31/12/1993, p. 2-266. According to Article 67, Hungary shall act to ensure that future legislation is compatible with Community legislation as far as possible.

${ }^{6}$ Article 11 (1) Agreements or concerted practices between undertakings and decisions by social organisations of undertakings, public corporations, associations or other similar organisations (hereinafter together: agreements), which have as their object or potential or actual effect the prevention, restriction or distortion of competition, shall be prohibited. Agreements concluded between undertakings, which are not independent of each other do not qualify as such kind of agreements.

${ }^{7}$ Article 21: It shall be prohibited to abuse a dominant position, particularly...

8 ,In order to attain these objectives - also taking into consideration the requirements of the approximation to the law of the European Community and the conventions of domestic competition law - Parliament passed the following Act."

${ }^{9}$ Council Regulation (EC) No 1/2003 of 16 December 2002 on the implementation of the rules on competition laid down in Articles 81 and 82 of the Treaty, OJ L 1, 4.1.2003., p.1-25.

10 on the history, reception of EU comeptition law see Tihamér Tóth: The reception and application of EU competition rules in Hungary: An organic evolution In: The law of the European Union in Hungary: Institutions, processes and the law, edited by Márton Varju and Ernő Várnay, HVG-Orac, Budapest, 2014

${ }^{11}$ C-32/11. Allianz Hungária Biztosító Zrt et al v. Gazdasági Versenyhivatal ECLI:EU:C:2013:160
} 
prohibition decision completely on the interpretation of Article 101, because the wording of the two provisions is almost identical. Consequently, the interpretation given by the ECJ on the meaning of Article 101 will have a binding effect on the interpretation of the national cartel prohibition. In its request for a preliminary ruling, the Supreme Court pointed out that there is a clear interest in having a uniform interpretation of the provisions and concepts of EU law. The ECJ declared its jurisdiction and argued that EU law has been rendered applicable by domestic law, which adopted for internal situations the same approach as that provided for under EU law. The wording of the preamble and the explanatory memorandum of the HCA on the approximation of Hungarian law to EU law was a significant argument of the Supreme Court and the ECJ alike.

In Hungary, judicial review of GVH decisions takes place at three levels. During the two instance ordinary review, courts examine the legality of the administrative decision based on points of law and facts. Afterwards, on points of law only, the Supreme Court reviews the judgements. ${ }^{12}$

The Hungarian Code on Civil Procedure ${ }^{13}$ sets the following limit on the competence of the two instance review courts: "An administrative decision rendered on a disretionary basis shall be considered lawful if the administrative body has approriately ascertained the relevant facts of the case, complied with the relevant rules of procedure, the points of discretion can be identified, and the reasoning of the decision demonstrates causal relation as to the weighing of evidence"14.

The Supreme Court sets aside the judgement of the review courts if it is incompatible with the law, or if any breach of procedural rules has occured, which had an impact on the merits of the case. ${ }^{15}$

Since the new Fundamental Law in Hungary came into force (2012) the Constitutional Court has the competence to review, on the basis of a constitutional complaint, court decisions for conformity with the Fundamental Law and to annul any court decision that is contrary to the Fundamental law. ${ }^{16}$

\section{PRACTISE OF THE HUNGARIAN COMPETITION AUTHORITY ${ }^{17}$}

Ten years after accession, 99 procedures were initiated by the GVH under double legal basis (i.e. under both EU and Hungarian law). Out of the 99 proceedings, 87 were closed until 1 May, 2014. Proceedings commenced under a double legal basis make almost $40 \%$ of the total number of cases. Out of the 87 proceedings closed, 14 were closed with a finding of violation with fines, 2 without fines, 8 commitment decisions were issued, in 16 proceedings, the proceeding was closed on the basis of lack of inter-state effect, in 2 proceedings, Article 101-102 were found inapplicable and in the majority of cases (45) the breach was not proven and the file was closed. The problem usually faced by the GVH is that at the beginning of its procedure, information gathered is not enough for the verification of a potential or actual effect on inter-state trade. Faced with the dilemma whether

\footnotetext{
${ }^{12}$ The Supreme Court cannot order the taking of evidence, its judgement is based on the file

${ }^{13}$ Act III of 1952 on the Code of Civil Procedure

${ }^{14}$ Article 339/B

${ }^{15}$ Article 275 (3)

${ }^{16}$ Article 24 (2) d, Basic Law. The so-called constitutional complaint procedure may be submitted when a right guarenteed by the Fundamental Law of the petitioner is violated by a judicial action and the possibilities for legal remedy have already been exhausted by the petitioner. Consequently, it is not a claim for judicial review.

${ }^{17}$ each data is taken from the Article written in Hungarian by Decsák Péter- Sárai József-Szilágyi Gabriella: The experience of the GVH in the application of EU competition law ten years after accession.) A 10 éves uniós tagság tapasztalatai a GVH jogalkalmazásának tükrében. Versenytükör 2014. 1. szám, pp.19-30.
} 
to commence a proceeding under EU competition law as well, the GVH tends to start the investigation under double legal basis. The reason for that being that cooperation with the European Competition Network is open only in proceedings based on EU Competition Law. ${ }^{18}$ This, on the other hand, results in the high number of proceedings (16) closed with the reasoning that the conduct is not capable of affecting trade between Member States.

Under Act CXL of 2004 on the General Rules of Administrative Proceedings and Services, the GVH shall assess each piece of evidence separately and as a whole and shall establish the facts according to its conviction based on this assessment. ${ }^{19}$

\section{CHAPTER 2}

\section{THE STANDARD OF PROOF AND JUDICIAL REVIEW IN EU COMPETITION LAW}

The ECJ has emphasised, relying on ECtHR case-law, that competition law does not belong to the hard core of criminal law and therefore the guarantees in matters of criminal law laid down in Article 6 of the ECHR will not necessarily apply with their full stringency. ${ }^{20}$ Therefore, it is quite difficult to draw the exact level of protection Member States and the European Union have to provide to companies charged by the violation of national or EU antitrust law.

\section{The standard of proof}

The standard of proof shows us the conditions which must be satisfied for facts to be regarded as proven.

Under settled caselaw of the ECJ, it is incumbent on the Commission to prove the infringements found by it and to adduce evidence capable of demonstrating to the requisite legal standard the existence of the circumstances constituting an infringement. ${ }^{21}$

According to constant ECJ practice, the Commission must establish „sufficiently precise and coherent proof" of an infringement, ${ }^{22}$ the Commission must provide a "firm, precise and consistent body of evidence" to justify its view. ${ }^{23}$

Alison Jones and Brenda Sufrin noted that ${ }^{24}$ a breach of the competition rules appears, therefore, to have to be established only on the balance of probabilities and the Commission does not have to

\footnotetext{
${ }^{18}$ p.24-25.

${ }^{19}$ Article 50 (6)

${ }^{20}$ see for example T-541/08, Sasol and others, ECLI:EU:T:2014:628, para 206

${ }^{21}$ C-185/95 P, Baustahlgewebe GmbH v Commission, ECLI:EU:C:1998:608, para 58, Claus-Dieter Ehlermann and Mel Marquis (eds): European Competition Law Annual 2009: The Evaluation of Evidence and its Judicial Review in Competition Cases, Hart Publishing, Oxford and Portland, Oregon, 2011.

${ }^{22}$ Case 29 and 30/83, Compagnie Royale Asturienne des Mines SA and Rheinzink GmbH v Commission [1984] ECR 1679.

${ }^{23}$ C-89/85, C-104/85, C-114/85, C-116/85, C-117/85 and C-125/85 to C-129/85, Ahlström Osakeyhtiö and Others v Commission [1993] ECR I-1307, para 127. See also Jacques Buhart, Romain Maulin: Proof in Cartels: State of Play and Perspectives. Concurrences No 4-2011, pp.51-64.

${ }^{24}$ Alison Jones and Brenda Sufrin: EU Competition Law, Oxford University Press, Oxford, 2014., p.126
} 
adduce proof beyond reasonable doubt of the existence of the infringement". However, any doubt of the Court must benefit the undertaking to which an infringement decision is addressed. ${ }^{25}$

The principle of unfettered evaluation of evidence applies, meaning that the only relevant criterion for the purpose of assessing the probative value of evidence lawfully adduced relates to its reliability. ${ }^{26}$ The intime conviction of the judge refers to the continental law systems in which the level of proof is the one that which is convincing for the court. ${ }^{27}$ According to Gippini-Fournier the law usually does not frame how strong this "personal conviction” of the judge should be.and that is the case with the EU Courts as well, which is not inclined to frame in general terms the standard of proof in competition cases. ${ }^{28}$

Under Court practice, it is not necessary for every item of evidence produced by the Commission to satisfy those criteria in relation to every aspect of the infringement. It is sufficient if the body of evidence relied on by the institution, viewed as a whole, meets that requirement. ${ }^{29}$ The ECJ takes a holistic view of the evidence by focusing on the body of evidence on which the Commission relies when viewed as a whole. ${ }^{30}$

\section{Standard of judicial review}

\footnotetext{
${ }^{25}$ Joined cases T-44/02 OP et al, Dresdner Bank AG and others, ECLI:EU:T:2004:302, para 60, Case T-441/08, International Confederation of Societies of Authors and Composers (CISAC) v Commission, ECLI:EU:T:2013:188. para 91. and T-348/08, Aragonesas Industrias y Energía SAU v Commission, ECLI:EU:T:2011:621, paras 92-93.,C199/92 P, Hüls AG v Commission, ECLI:EU:C:1999:358, para 149-150.

26.C-411/04 Salzgitter Mannesmann GmbH v Commission, ECLI:EU:C:2007:54, para 45.,Opinion of Judge Vesterdorf acting as Advocate General of 10 July 1991 in Case T-1/89, Rhône-Poulenc v Commission, ECLI:EU:T:1991:38, at page II-954., Joined Cases T-67/00, T-68/00, T-71/00 and T-78/00, JFE Engineering Corp,ECLI:EU:T:2004:221, para 273

Heike Sweitzer claimes that „with a view to Article 101 and Article 102 decisions imposing fines, a significantly higher standard of proof applies, analogous to what in the common law system would be qualified as „beyond reasonable doubt". (In: Ioannis Kokkoris 'The Reform of EC Competition Law: New Challanges In Mel Marquis and Roberto Cisotta (eds): Litigation and Arbitration in EU Competition Law, Edward Elgar Publishing, 2015, p. 113.) She refers to the Siemens judgement ${ }^{26}$, according to which the Court must come to a "firm convinction" that the alleged infringment took place. She is

In the Toshiba judgement in 2014 the General Court allegedly raised the standard of proof to beyond reasonable doubt, as it has declared that "the evidence submitted by the Commission must permit the conclusion beyond all reasonable doubt that there was an infringement." As that judgement has not yet been confirmed by the ECJ, the prevailing view applies according to which the balance of probabilities standard is enough to be satisfied by the Commission. See T-519/19, Toshiba Corp v Commission, ECLI:EU:T:2014:263 and the appeal pending:C-373/14. P.

27 Eric Gippini-Fournier: The Elusive Standard of Proof in EU Competition Cases http://papers.ssrn.com/sol3/papers.cfm?abstract id=1433744, p.5., Per Hellström: A Uniform Standard of Proof in EU Competition Proceedings IN: Claus-Dieter Ehlermann and Mel Marquis (eds): European Competition Law Annual 2009: The Evaluation of Evidence and its Judicial Review in Competition Cases, Hart Publishing, Oxford and Portland, Oregon, 2011.

http://papers.ssrn.com/sol3/papers.cfm?abstract id=2147705, p.2.

28 Eric Gippini-Fournier: The Elusive Standard of Proof in EU Competition Cases http://papers.ssrn.com/sol3/papers.cfm?abstract id=1433744, p.5 and p. 9.

${ }^{29}$ Joined Cases C-238/99 P, C-244/99 P, C-245/99 P, C-247/99 P, C-250/99 P to C-252/99 P and C-254/99 P Limburgse Vinyl Maatschaapij and Others v Commission, ECLI:EU:C:2002:582, paragraphs 513 to 523

${ }^{30}$ Ioannis Kokkoris: The Reform of EC Competition Law: New Challanges In Mel Marquis and Roberto Cisotta (eds): Litigation and Arbitration in EU Competition Law, Edward Elgar Publishing, 2015., p.114., see Joined cases T-305/94 to T-307/94 Linburgse Vinyl Maatschappij and others v Commission (PVC II.) ECLI:EU:T:1999:80, para 768 to 778 and recent cases Toshiba, para 38 and Intel v Commission para 64.
} 
Jones and Sufrin note that "the question of the intensity of the review in which the Geneal Court engages when reviewing Commission competition decisions is a burning issue. (...)As the Commission is not a tribunal for the purposes of Article 6 (1) of the ECHR or Article 47 of the Charter the supervision by the GC must satisfy the requirement fro a fair and public hearing before an independent and impartial tribunal if the competition proceedings are to comply with the Convention and the Charter., ${ }^{31}$

Recently in the Microsoft judgement the Court observed that it follows from consistent case-law that, although as a general rule the Community Courts undertake a comprehensive review of the question as to whether or not the conditions for the application of the competition rules are met, their review of complex economic appraisals made by the Commission is necessarily limited to checking whether the relevant rules on procedure and on stating reasons have been complied with, whether the facts have been accurately stated and whether there has been any manifest error of assessment or a misuse of powers. ${ }^{32}$

Likewise, in so far as the Commission's decision is the result of complex technical appraisals, those appraisals are in principle subject to only limited review by the Court, which means that the Community Courts cannot substitute their own assessment of matters of fact for the Commission's. 33

However, while the Community Courts recognise that the Commission has a margin of appreciation in economic or technical matters, that does not mean that they must decline to review the Commission's interpretation of economic or technical data. The Community Courts must not only establish whether the evidence put forward is factually accurate, reliable and consistent but must also determine whether that evidence contains all the relevant data that must be taken into consideration in appraising a complex situation and whether it is capable of substantiating the conclusions drawn from it. ${ }^{34}$

In the KME Germany $v$ Commission and Chalkor $v$ Commission judgement ${ }^{35}$ the issue of the Commission's margin of discretion with regard to the complex economic and techical matters was challenged again by pleading the violation of Article 6 (1) of the ECHR. By that time the ECtHR has issued its well-known Menarini judgement. Although the ECJ has not referred explicitly to Menarini in $\mathrm{KME}$, it has repeated its interpretation discussed above, the effect of which is that in its view its own interpretation is in conformity with the Charter and supposedly with ECHR jurisprudence. The Commission"s margin of appreciation does not mean that the Court of the European Union must refrain from reviewing the Commission's interpretation of information of an economic nature. ${ }^{36}$ According to Igor Nikolic "the courts limit themselves to verifying whether the Commission has

\footnotetext{
${ }^{31}$ Alison Jones and Brenda Sufrin: EU Competition Law, Oxford University Press, Oxford, 2014., p.1029

${ }^{32}$ T-201/04, Microsoft Corp. v Commission, ECLI:EU:T:2007:289, para 87-89.

33 para 88.

${ }^{34}$ para 89.

${ }^{35}$ C-272/19 P, ECLI:EU:C:2011:810

${ }^{36}$ C-272/19 P, KME Germany v Commission, ECLI:EU:C:2011:810, paras 94, 102.,C-386/10 P, Chalkor AE Epexergasias Metallon v Commission,ECLI:EU:C:2011:815, para 54. See also Igor Nikolic: Full judicial review of antitrust cases after KME: a new formula of review? E.C.L.R. 2012, 33(12), 583-588
} 
applied the Fining Guidelines correctly, and in doing so, it will only look for manifest errors of appraisal. The General Court often did not engage in significant proportionality review of fines." ${ }^{37}$

On the other hand, the ECJ in Otis ${ }^{38}$ held that the review provided by the Treaty meets the requirements of the principle of effective judicial protection in Article 47 of the EU Charter of Fundamental Rights. ${ }^{39}$

Recently Pieter Van Cleynenbreugel pointed out the difference between comprehensive and limited review and the tendency of the ECJ to submit more cases to a comprehensive review. ${ }^{40}$ The comprehensive review consists in an exhaustive review of both the findings of facts and the legal appraisal of those facts. ${ }^{41} \mathrm{~A}$ limited review takes place if the Union Courts confine their review to whether the Commission has committed a manifest error of assessment.

Under the limited review Commssion is capable not only to develop the competitive harm theory, but also to decide occasionally on policy issues. José Carlos Laguna de Pazalso reflected on the "need to strike the right balance between the conflicting forces of improving courts' scrutiny as a means to protect the citizens' rights, on the one hand, and leaving the competition authority the necessary room to shape and implement competition policy, on the other." ${ }^{\prime 2}$

Pieter Van Cleynenbreugel on the other hand, claims that "rhetoric does not match results in this area of the law" ${ }^{43}$ In his view recent case-law demonstrates that the application of the comrehensively tailored review amounts to de facto deference to the Commission's interpretation of facts and classifications in law and that the Court of Justice appears unwilling to determine-as a matter of EU law-clear-cut standars in accordance with which the General Court has to take account of tailored pleas and the margin of appreciation entrusted to the Commission. ${ }^{44}$

De facto review

\footnotetext{
${ }^{37}$ Igor Nikolic: Full judicial review of antitrust cases after KME: a new formula of review? E.C.L.R. 2012, 33(12), 583-588., at page 587. Wouter P.J:Wils has also admitted that with regard to the amount of the fine, Regulation 1/2003, the case law of the EU Courts and the Guidelines and Leniency Notice still leave the European Commission a significant margin of discretion. Wouter P.J.Wils: The compatibility with fundamental rights of the EU antitrust enforcement system in which the European Commission acts bot has investigator and as first-instance decisin maker http://papers.ssrn.com/sol3/papers.cfm?abstract id=2363440, at page 13 . Nonetheless, his final conclusion is that the combination of the review of legality and this unlimited jurisdiction meets the "full jurisdiction" standard laid down int he case law of the European Court of Human Rights. at $p$. 14.

${ }^{38}$ C-199/11 Europese Gemeenschap v Otis and others, ECLI:EU:C:2012:684,

39 paras 56-63

40 Pieter Van Cleynenbreugel: Efficient justice in the service of justiciable efficiency? Varieties of comprehensive judicial review in a modernised EU competition law enforcement context. The Competition Law Review, Volume 10, Issue 1, pp35-6, at p.37.

41 p.37.

42 José Carlos Laguna de Paz: Understanding the limits of judicial review in European competition law, Journal of Antitrust Enforcemnet, Vol.2, No. 1 (2014), pp.203-224, at p.204.

43 p. 41.

${ }^{44}$ p.44. He is relying on the judgements of Schindler and Kone. C-501/11P, Schindler Holding Ltd and others v Commission, ECLI:EU:C:2013:522 and C-510/11P, Kone Oyj et al v Commission, ECLI:EU:C:2013:696
} 
As the President of the General Court has noted, the Court is marginalising the marginal review test, and therefore the tendency is to put each case under the full review test. ${ }^{45}$

This view is confirmed by other academics citing among others the Telefonica ${ }^{46}$ and Deutsche Telekom ${ }^{47}$ judgements to reason that the Commission's leeway has been considerably reduced by several decades of case law, which set out standards of proof and very detailed interpretation criteria. ${ }^{48}$ The marginal review test probably has also reflected the institutional divison between the Commission and the Court under which the Court has refrained to engage in its own appraisal based on a different methodology than the Commission. ${ }^{49}$

The ECJ's interpretation of the required standard of proof to be met by the Commission does not necessarily has a determinative effect the standard of proof applied by the national competition authorities and national courts, because, according to Recital 5 of Regulation 1/2003/EC ${ }^{50}$, the regulation affects neither national rules on the standard of proof nor obligations of competition authorities or courts of the Member States to ascertain the relevant facts of a case, provided that such rules and obligations are compatible with general principles of Community law.

Thus, decentralisation of the application of Articles 101-102 does not result in the obligation on national enforcers to apply the same standard of proof as that applied by the ECJ.

\section{CHAPTER 3.}

\section{THE STANDARD OF PROOF AND JUDICIAL REVIEW DEBATE IN HUNGARY ${ }^{51}$}

Recently the most important question raised by the parties at national court level was whether review of a GVH decision by the competent administrative courts is penal or administrative by

\footnotetext{
45 Marc Jaeger: The Standard of Review in Competition Cases Involving Complex Economic Assessments:Towards the Marginalisation of the Marginal Review? (2011) 2:4 Journal of European Competition Law \& Practice: 295-314. See also teh Editorial comment sin October 2011 issue of The Common Market Law Review: "... generally, the "margin of appreciation"doctine ha not prevented the General Court from looking into any economic or technical detail of a case that appeared remotely promising as a basis for a successful ground of appeal. Therefore, much would be won of the Couret stopped paxing lip-service to the old "complex appraisals" formula.."

${ }^{46}$ T-336/07 Telefónica SA and Telefónica Espaňa SA v Commission, ECLI:EU:T:2012:172, paras 110-144.

47 T-271/03, Deutsche Telekom AG v Commission, ECLI:EU:T:2008:101, para 185. and on appeal C-280/08. P, ECLIEU:C:2010:603

${ }^{48}$ José Carlos Laguna de Paz: Understanding the limits of judicial review in European competition law, Journal of Antitrust Enforcemnet, Vol.2, No. 1 (2014), pp.203-224, p.216. Heike Schweitzer also explains that "the intensity of judicial control exercised by the GC does not decrease, but rather increase wit the complexity of the fact patters and the economic assessment at issue." p. 511.

${ }^{49}$ Heike Schweitzer, p. 512.

${ }^{50}$ Council Regulation (EC) No 1/2003 of 16 December 2002 on the implementation of rules on competition laid down in Article 81 and 82 of the Treaty, OJ L 1, 04/01/2003., pp.1-25.

51 see the study of Nagy Csongor István in Hungarian: Tisztességes eljárás és bírósági felülvizsgálat a versenyfelügyeleti eljárásban. In Verseny és szabályozás 2014 (szek.: Valentiny Pál, Kiss Ferenc László, Nagy Csongor István) MTA KRTK Közgazdaság-tudományi Intézet, pp.55-72., http://econ.core.hu/file/download/vesz2014/felugyelet.pdf
} 
nature? Given that different arguments and answers surfaced, the debate was finally decided by the Supreme Court and the Constitutional Court. ${ }^{52}$

To follow the judgements in chronological order, we first summarise the judgement of the Supreme Court from May 2014.

\section{JUDGEMENT OF THE SUPREME COURT ${ }^{53}$}

Several years ago the GVH found a bid-rigging cartel created back in 2004, adopted a negative decision under Article 101 TFEU and Article 11 of the HCA and fined the participant undertakings quite heavily. The leniency applicant received immunity from the fine. The legality of the decision and judgements issued by the review courts was challenged before the Supreme Court.

The central question of this case was the standard of proof in competition law procedures. The parties challenged the decision on the ground that the GVH cannot rely on evidence coming only from one source, namely the leniency applicant. In their submission it would not fulfil the standard of proof, that is "beyond reasonable doubt" as established by the jurisprudence of the European Court of Human Rights. ${ }^{54}$ Hence, the plaintiff claimed the violation of its right to a fair trial ${ }^{55}$ under the European Convention on Human Rights. ${ }^{56}$

The GVH argued that the standard of proof is not the "beyond reasonable doubt" test, but that applied by the ECJ. According to this reasoning, the ECJ accepted evidence originating from one single source, if the evidence was consistent and sufficiently precise.

The Supreme Court noted at the outset that the penal nature of the fine has the consequence that the procedural guarantees flowing from the jurisprudence of the European Court of Human Rights have to be respected. The Supreme Court relied especially on the Menarini judgement.

The Supreme Court found that the fine applied by the GVH is of a criminal nature, but that does not mean that the court should review the decision in a penal procedure or under that the test is "beyond reasonable doubt." According to the Supreme Court the ECHR, as interpreted in the Menarini judgement, does not oblige national courts to apply a specific standard of proof, because standards of proof applied in civil procedures are different in the Member States. Legal doctrine in some countries, like in Hungary, has not developed a uniform standard of proof applicable in each civil law proceedings.

\footnotetext{
52 for earlier literature see in Hungarian: Ruszthiné Juhász Dorina- Zavodnyik József: A bizonyítási mérce, a bizonyítási teher és a bizonyítékok értékelése versenyügyekben, Jogtudományi Közlöny, 2014/6., pp.286-299.

${ }^{53}$ Kfv. III.37.690/2013/29. Case annotation by Dorkó Dalma in Hungarian in Versenytükör. Dorkó Dalma: Vasútépítő kartell a Kúria ítéletének tükrében. Versenytükör 2014/1, pp.69-77.

${ }^{54}$ The judges relied on the following judgements: Case Engel and others $\vee$ The Netherlands, Application no. 5100/71, 5107/71, 5102/71, 5354/72, 5370/72, 08/06/1976, Case Öztürk v Germany,Application no. 8544/79, 21/02/1984, Case Jussila v. Finland, Application no. 73053/01, 23/11/2006, Case Menarini Diagnostics S.R.L. v Italy, Application no. 43509/08, 27/09/2011

${ }^{55}$ Article 6

${ }^{56}$ Convention for the Protection of Human Rights and Fundamental Freedoms, Article 6 (1): In the determination of his civil rights and obligations or of any criminal charge against him, everyone is entitled to a fair and public hearing within a reasonable time by an independent and impartial tribunal established by law. ...
} 
In the Supreme Court's view, ordinary courts should view the GVH's decision as an indictment in penal law and during judicial review the plaintiffs can prove that a more reasonable assessment of the evidence exists.

With regard to the standard of judicial review in the Supreme Court's judgement the plaintiffs do not have to prove that the competition authority has exercised its discretion in a gravely unreasonable manner.

Ordinary courts cannot rely on the limits of review set by the Hungarian Code on the Civil Procedure in Article 339/B, full review of the discretionary powers of the competition authority should be exercised by the Hungarian courts.

It is in line with the Menarini judgment that Hungarian procedural law limits the competence of the Supreme Court to review judicial decisions on points of law only, because the two level ordinary court review fulfils the requirements of full judicial review as flowing from the Menarini judgement.

Concerning the evidence of the GVH in the given case, the Supreme Court has noted that also the ECJ had accepted evidence coming only form one source if the evidence was consistent and sufficiently precise. Hence, the Supreme Court was willing to approve the findings of the GVH in that respect.

In consequence, the leniency application of a cartelist and the document obtained during the dawn raid as found sufficient to prove the existence of the cartel.

Furthermore, the parties made a motion to the Supreme Court to initiate a preliminary ruling procedure at the ECJ on the interpretation of the applicable standard of proof.

The Supreme Court has refused to ask for a preliminary ruling by stating that according to the CILFIT judgement ${ }^{57}$ it is not obliged to do that, because the ECJ has extensive case-law on that point.

Apart from the ECtHR case-law, the Supreme Court has noted that Article 52 (3) of the EU Charter of Fundamental Rights incorporates the ECtHR jurisprudence in those cases where the Member State's implement Union law. ${ }^{58}$ By applying Article 101 Hungary implements Union law, resulting in the obligation for national court to set aside national law not in conformity with the ECHR. The Supreme Court explicitly ruled that Article 339/B of the Procedural Code has to be set aside as incompatible with the ECHR.

Another considerable statement of the Supreme Court was the implication flowing from Article 3 (2) of Regulation 1/2003. That article contains the so-called convergence rule according to which the application of national competition law may not lead to the prohibition of agreements, decisions by associations of undertakings or concerted practices which may affect trade between Member States but which do not restrict competition within the meaning of Article 81(1) of the Treaty, or which fulfil the conditions of Article 81(3) of the Treaty or which are covered by a Regulation for the application of Article 81(3) of the Treaty. In the Supreme Court's view, this provision is also applicable for the

\footnotetext{
${ }^{57}$ C-283/81, Srl CILFIT and others v Ministry of Health, ECLI:EU:C:1982:335

58 "In so far as this Charter contains rights which correspond to rights guaranteed by the Convention for the Protection of Human Rights and Fundamental Freedoms, the meaning and scope of those rights shall be the same as those laid down by the said Convention. This provision shall not prevent Union law providing more extensive protection."
} 
determination of standard of proof in Article 101 cases, nonetheless the wording of it is confined to the legal assessment. The contrary view would lead to the prohibition of cartels by national competition authorities or courts that are to considered as compatible with Article 101 by the European Commission or by the ECJ. This, in turn, would not only violate the principle of uniform application of Union law, but also hamper the achievement of the objectives of Article 101.

\section{JUDGEMENT OF THE CONSTITUTIONAL COURT}

In parallel with the review of the cartel decision forming the subject matter of the judgement of the Supreme Court, another cartel decision was reviewed by ordinary courts and later by the Constitutional Court. ${ }^{59}$ The competition authority has found a single and continuous infringement of Article 11 of the Hungarian Competition Act in the so-called road construction bid-rigging cartel case. The petitioner claimed that the judgement of the Supreme Court violates its fundamental rights.

In September 2014, the Constitutional Court has rendered its judgement on the same questions of law as those answered by the Supreme Court in the railway cartel case discussed above. The petitioner practically challenged the entire system of competition law enforcement in Hungary. This summary is focusing only on the most important allegations.

The first head of claim of the petitioner was about the violation of its right to a fair trial, as the Competition Authority itself had charged it with the cartel and imposed fines on it. In its second claim the undertaking alleged the breach of its right to presumption of innocence, because the Supreme Court has based its decision on a single piece of evidence. The third head of claim concerned the violation of the right to a fair trial again, on the basis of the fact that Supreme Court has weighed the evidence without having a competence under Hungarian procedural rules to do so.

In sum, the arguments centered around the administrative or penal nature of the review proceeding and the standard of proof and weighing of evidence.

The Constitutional Court first recalled Article 6 (1) of the European Convention on Human Rights ${ }^{60}$ and Article 47 of the EU Charter of Fundamental Rights ${ }^{61}$ on the right to a fair hearing and interpreted Article XXVIII of the Hungarian Basic Law ${ }^{62}$ in this international context. Another right relied on by the applicant was the right to the presumption of innocence ${ }^{63}$ and nullum crimen sine

\footnotetext{
${ }^{59}$ Decision of the Constitutional Court of 30 September, 2014 (No.30/2014. (IX.30.) Case annotation by László Bak in Hungarian in Versenytükör. Bak László: Alkotmányos versenyjog-a versenyfelügyeleti eljárás az Alkotmánybíróság fókuszában. Versenytükör pp. 52-60

${ }^{60}$ Convention for the Protection of Human Rights and Fundamental Freedoms, Act XXXI of 1993. On the relationship of the Convention, EU Charter of Fundamental Rights and Hungarian Constitutional Law see Juhász Miklós: Kriminális versenyjog? - gondolatok az emberi jogok és a versenyjog kapcsolatáról, Magyar Jog 2013.9. szám, pp 515-524. See also a Hungarian ECHR case: DEBÚT Zrt and others v Hungary, application o 24851/10, $20 / 11 / 2012$

${ }^{61}$ Charter of Fundamental Rights of the European Union, OJ C 326, 26.10.2012., p.391-407.

${ }^{62}$ Basic Law of Hungary, 25 April 2011, Article XXVIII (1) "Everyone shall be entitled to have any charge against him or her, or his or her rights and obligations in any litigation, adjudicated within a reasonable time in a fair and public trial conducted by an independent and impartial court established by an Act."

${ }^{63}$ Convention for the Protection of Human Rights and Fundamental Freedoms, Article 6 (2), Charter of Fundamental Rights of the European Union, Article 48, Fundamental Law, Article XXVIII (2) „No one shall be considered guilty until his or her liability under criminal law has been established by the final decision of a court."
} 
lege, nulla poena sine lege ${ }^{64}$. The petitioner claimed that as the decision of the competition authority was based on the single and continuous infringement, a concept unknown in Hungarian competition law, its right to nullum crime sine lege was violated during the procedure.

At the outset, the Constitutional Court held that the procedure in front of the Competition Authority has to be considered as having a criminal nature under ECHR and ECJ jurisprudence. ${ }^{65}$ The Court proceeded by arguing that entrusting the prosecution and punishment of breaches of competition rules to administrative authorities is not inconsistent with the ECHR or the EU Charter of Fundamental Rights in so far as the person concerned has an opportunity to challange any decision made against him before a tribunal that offers guarantees.

The Court argued that any violation of fundamental rights can be avoided by having a full review provided by a judicial body. The characteristics of such a body include the power to quash in all respects, on questions of fact and law, the decision. The judicial body must in particular have jurisdiction to examine all questions of fact and law relevant to the dispute before it. $^{66}$

The Court has contended that the principles claimed by the petitioner and enshrined in the international documents and in the Hungarian Fundamental Law should be applied also in competition proceedings outside the ambit of Hungarian penal law, but the level of protection is lower than in penal proceedings as competition proceeding does not belong to the hard core of criminal law. ${ }^{67}$

The above statement has considerable consequences also on the standard of proof. The Court, without saying anything specific about the applicable standard of proof in Hungarian law, has underlined that the standard of proof is not that of beyond reasonable doubt. It was further suggested by the Court that the Competition Authority has to base its decision on consistent, direct or indirect, evidence.

The review court has the obligation to assess the evidence produced by the Authority. The judge has to weigh freely the evidence produced by the Authority.

By turning back to the question of full judicial review, the Court observed that under Article 339 (1) and (2) of the Procedural Code, Hungarian courts have the competence to annul the decision, to order reopening and to alter the decision itself. Furthermore, courts have the competence to order the taking of evidence as well. Nonetheless the text of Article 339/B of the Procedural Code sets a limit on the competence of cours to review the administrative decisions based on discretion, in practice, reviewing the fines, courts have the competence to overrule de facto the discretion exercised by the HCA with the reasoning that the facts established by the court are in contradiction with the records.

\footnotetext{
${ }^{64}$ Article 48 of the Charter for the Protection of Human Rights and Fundamental Freedoms, Hungarian Fundamental Law, Article XXVIII (4):" No one shall be found guilty and subjected to punishment for an act that, at the time it was committed, was not a criminal offence under the law of Hungary or - within the sphere specified by an international treaty or a legal act of the European Union - under the law of another State."

${ }^{65}$ Engel, Jussila v. Finnland, Janosevic v Sweden, Menarini cases were referred to by the Constitutional Court from the ECHR jurisprudence, and C-501/11.P. Schindler v Commission, ECLI:EU:C:2013:522, was referred to from the case-law of the ECJ.

${ }^{66}$ para 65 of the decision

${ }^{67}$ my emphasis, para 62 of the decision
} 
In the second part of its the decision, the Constitutional Court interpreted the petitioner's right to the presumption of innocence and whether this right was violated as there was a single piece of evidence relied on by the Competition Authority. Part of that right is the principle of in dubio pro reo under which if reasonable doubt remains, the accused is to be acquitted. After citing ECJ judgements in cases E.ON Energie $v$ Commission $^{68}$, Baustahlgewebe $v$ Commission $^{69}$, United Brands ${ }^{70}$ the Constitutional Court came to the conlusion that the in dubio pro reo principle has to be respected by the Competition Authority and by the review courts. That means in practice that the GVH has to rely on consistent and convergent evidence, not on speculations or hypothesis. ${ }^{71}$ The body of evidence cannot contain conflicting evidence, it should be consistent by nature. On the other hand, the probative force of the evidence has to be decided by the judge relying on his or her own conviction. Hence, the Constitutional Court has no competence to overrule the probative force of evidence determined by judges. With this the Constitutional Court established that Hungarian courts have to rely on their intime conviction in competition procedures.

The petitioner claimed the breach of the principle of nullum crimen sine lege as well, arguing that the concept of single and continuous infringement is unknown in Hungarian law and therefore the violation of competition rules was not foreseeable. In this context the Constitutional Court has pointed out that the concept developed by the ECJ is not a new form of conduct, but a series of several individual conducts already declared incompatible with law. Criminal charges can be determined legally not only by the legislator and also by the jurisprudence if the illegality of the conduct is foreseeable. The Constitutional Court hinted that the latter was the case.

\section{CHAPTER 4}

\section{CONCLUSION}

We can see that the eagerly awaited judgements of the Supreme and Constitutional Court have considerable implication in practice. The standard of proof and judicial review debate is to be closed in Hungary. Lower courts charged with the everyday application of EU and national antitrust rules should follow the decisions of the Supreme and the Constitutional Court. From the anysis above it can be seen that the Constitutional Court has remained faithful of the jurisprudence of the ECHR, nonetheless the EU Charter provides room for stricter protection for fundamental rights. The Constitutional Court established that Hungarian courts have to rely on their intime conviction in competition procedures.

On the other hand, the Supreme Court has set aside a procedural rule in the Hungarian Procedural Code by arguing that the full review requirement of the ECHR is not fulfilled otherwise. "De iure" full review provides more protection for undertakings than de facto practice of courts.

It is interesting to note that the Supreme Court has decided not to ask for a preliminary ruling, instead it has interpreted the convergence rules of Regulation 1/2003/EC, the requirement of uniform application of competition law and EctHR case-law alone. After the Supreme Court's ruling

\footnotetext{
${ }^{68}$ C-89/11.P, ECLI:EU:C:2012:738

${ }^{69}$ C-185/95.P,ECLI:EU:C:1998:738

70 27/76, ECLI:EU:C:1978:22

${ }^{71}$ para 71.
} 
standard of judicial review is based Hungary on de iure full review which seems higher than the standard provided currently by Union law ${ }^{72}$.

\footnotetext{
${ }^{72}$ Nagy Csongor István in Hunngarian: Tisztességes eljárás és bírósági felülvizsgálat a versenyfelügyeleti eljárásban. In Verseny és szabályozás 2014 (szek.: Valentiny Pál, Kiss Ferenc László, Nagy Csongor István) MTA KRTK Közgazdaság-tudományi Intézet, pp.55-72., http://econ.core.hu/file/download/vesz2014/felugyelet.pdf, p.62.
} 